Paedagogia Christiana

I/27 (20I I) - ISSN 1505-6872

Piotr Krajewski*

Olsztyn

\title{
Integrująca rola religii w wychowaniu ekologicznym
}

W licznych publikacjach i środkach masowego przekazu często podkreśla się znaczenie ustawicznego podnoszenia świadomości ekologicznej, która powinna być jednym z efektów realizowania celów edukacyjnych oraz informowania o stanie środowiska przyrodniczego. Edukacja zorientowana jest na uaktywnienie procesów myślenia, procesów reorientacji postaw ludzkich wobec przyrody, wyrażających się zmianą postępowania w życiu osobistym, społecznym, kulturalnym i polityczno-gospodarczym. Jednakże pomimo znacznego postępu nadal zauważa się poważny deficyt zrozumienia, co wywołane jest szczątkową wiedzą na ten temat i brakiem pełnej informacji stosownej do powagi sytuacji ${ }^{1}$.

Niniejsza publikacja nie ma na celu opisywania zmian zachodzących w środowisku życia człowieka, które w sposób oczywisty oddziałują na standardy życia indywidualnego i społecznego; w zamiarze ma silniej zaakcentować potrzebę edukacji ekologicznej jako elementu formacji całego człowieka. Wychowanie to sztuka nawiązywania relacji z samym sobą, z innymi ludźmi i z otoczeniem. Nawiązywanie relacji z otoczeniem jest jednocześnie „współstworzeniem" nie tylko w wymiarze materialnym i intelektualnym, ale i duchowym, który to nadaje sens zarówno materii, jak i przeżyciom rozumu, ponieważ spojrzenie przez pryzmat wiary pozwala dojrzeć logikę fenomenu życia i pozycji człowieka pośród elementów przyrody ożywionej i nieożywionej.

* Dr Piotr Krajewski, adiunkt na Wydziale Prawa i Administracji Uniwersytetu Warmińsko-Mazurskiego w Olsztynie.

${ }^{1}$ Por. M. D. Kamecka, Cel ekoedukacji. Wiedza czy postawa?, „Człowiek i Światopogląd" 5 (1985), s. 76-83. 


\section{Potrzeba edukacji proekologicznej w kontekście zmian społeczno-kulturowych}

Postawa rozumiana jako stosunek człowieka do życia, do pewnych zjawisk, jako pogląd na dany temat, kształtuje się na podstawie przeżytych doświadczeń. Odnosi się to również do zagadnień ekologii i zagrożenia środowiska ${ }^{2}$. Kształtowanie postaw proekologicznych pobudza wrażliwość na procesy i zjawiska naturalne, na bogactwo i różnorodność gatunków, a przez to rozwija również tolerancję i poszanowanie dla innych. Wszystko to jednak uzależnione jest w równej mierze od przyjętej hierarchii wartości, ukształtowanej wyobraźni, uczuć i woli, co od stopnia odpowiedzialności i stosunku do wszelkich form życia na czele, $\mathrm{z}$ poczuciem więzi z innymi ludźmi ${ }^{3}$. Iluzją natomiast jest przekonanie, że to, co związane jest z cywilizacją i z technicznym geniuszem człowieka, jest lepsze i doskonalsze od tego, co pierwotne i naturalne $e^{4}$.

Rozwijanie postaw proekologicznych można najpierw traktować jako przejaw przełamania wielowiekowej rywalizacji z siłami natury, a następnie przekonanie się o możliwościach oraz konieczności podjęcia działań zmierzających do ochrony środowiska i to nie tylko w wymiarze globalnym, ale i lokalnym, a nawet indywidualnym. Prawdą jest, że jedynie zrozumienie powagi sytuacji przez całą społeczność świata daje gwarancję sukcesu, do którego droga wiedzie wyłącznie poprzez świadomość odpowiedzialności jednostek na własnym, indywidualnym odcinku działania prywatnego i społecznie użytecznego 5 .

Nie trzeba nikogo przekonywać, iż właśnie dzisiaj, bardziej niż kiedykolwiek w przeszłości, istnieje potrzeba nawiązywania współpracy w kwestii ochrony środowiska poprzez opracowywanie skutecznych instrumentów działania oraz strategii powstrzymania procesów destrukcyjnych wszystkich ekosystemów, przede wszystkim poprzez skuteczną edukację ekologiczną ${ }^{6}$.

2 Postawa to wynik całego potencjału rozwojowego jednostki, doświadczeń z przeszłości, wychowania, obserwacji, przemyśleń, poziomu wrażliwości intelektualnej. Bezpośrednio wiąże się ze sferą uczuć, wolą, przyjętą hierarchią wartości. Uzewnętrzniana może prowadzić do ukształtowania w człowieku pozytywnego lub negatywnego stosunku do własnego otoczenia. Szeroka edukacja ekologiczna może w tym znacznie pomóc.

${ }^{3}$ Por. M. D. Kamecka, dz. cyt., s. 80.

${ }^{4}$ Por. W. Tyburski, Pojednać się z Ziemiq. W kręgu zagadnień humanizmu ekologicznego, Torun 1993, s. 89.

5 Por. M. D. Kamecka, dz. cyt., s. 81.

${ }^{6}$ Zagadnieniem tym poważnie zajęło się ONZ przedstawiając opracowane przez siebie cele, które winny przyświecać przedsięwzięciom edukacyjnym. Należą do nich: zapewnienie 
Ochrona przyrody wymaga działań praktycznych. Nie jest to jednak możliwe bez wcześniejszego zaznajomienia się z podstawowymi zagadnieniami rządzącymi ekologią7. Temu właśnie mają służyć programy edukacyjne realizowane na wszystkich poziomach kształcenia. Dziś wszyscy zdają sobie sprawę, że nie jest to kaprys mody, ale realna i nagląca potrzeba, gdyż degradacja walorów naturalnych wiąże się ze wszystkimi innymi problemami współczesności: walką z głodem, dostarczaniem wody pitnej, zapewnieniem energii, niepokojącymi zjawiskami demograficznymi czy utrzymaniem pokoju na świecie. Pomimo wzrostu świadomości, iż ochrona środowiska przyrodniczego i ludzkiego w skali globalnej jest warunkiem przetrwania, zanieczyszczenie biosfery wciąż rośnie ${ }^{8}$. Nie jest to zjawisko całkiem nowe; w sposób ewidentny problem - początkowo niedostrzegany a następnie ukrywany - narastał od początku ery przemysłowej. Dziś należy do najczęściej poruszanych, prawie modnych ${ }^{9}$. Efektem tego są naciski na kształtowanie postaw proekologicznych, co wiąże się z podnoszeniem kultury technicznej, standardów miejsca zamieszkania, pracy i wypoczynku. Pojawiła się też potrzeba rozbudzania refleksji nad skutkami własnej aktywności oraz poczucia odpowiedzialności za warunki życia wobec następnych pokoleń. Wyrobienie w sobie tej umiejętności pozwoli na niebudzące obaw wykorzystanie nowoczesnych technik i analiz komputerowych, analiz zasobów, prognozowanie

każdemu człowiekowi warunków do kształtowania własnych postaw, przekonań i wartości oraz zdobywania wiedzy i umiejętności służących ochronie środowiska społeczno-przyrodniczego; proponowanie wzorów zachowań jednostek, grup i całych społeczeństw sprzyjających zgodnemu współistnieniu człowieka z naturą; kształtowanie świadomości istnienia wzajemnych powiązań między ambicjami polityki, wymogami ekonomii, oczekiwaniami społeczeństwa i potrzebami środowiska. Por. A. Papuziński, Edukacja ekologiczna a etyka środowiska w świetle dyskusji na temat racjonalności pedagogiki, w: W. Tyburski (red.), Etyka środowiskowa. Teoretyczne i praktyczne implikacje. Torun 1998, s. 54.

${ }^{7}$ Ekologia jest nauką biologiczną, zajmującą się zależnościami, które decydują o występowaniu i rozmieszczeniu organizmów żywych w obrębie poszczególnych siedlisk ekosystemu. Por. C. J. Krebs, Ekologia. Eksperymentalna analiza rozmieszczenia i liczebności, Warszawa 1996, s. 3.

${ }^{8}$ Pośrednim przejawem tego jest wzrost ilości „chorób zawodowych”, absencji chorobowych, inwalidztwa, na terenach wysoko uprzemysłowionych i o dużym natężeniu ruchu kołowego. Por. J. W. Dobrowolski, Moralna odpowiedzialność naukowców za ekologiczna profilaktykę chorób a zastosowanie nowych metod badań zwiqzanych z bioelektronikq. Rozważania na tle obecnego modelu ksztatcenia studentów, w: W. Sedlak, J. Zon, M. Wnuk (red.), Bioelektronika. Materiały VI Sympozjum. Katolicki Uniwersytet Lubelski, Lublin, 20-21 listopada 1987, Lublin 1990, s. 134.

9 Por. S. Olejnik, Ochrona środowiska - problem sumienia, w: S. C. Napiórkowski, W. Koc (red.), Chronić by przetrwać. Materiały sympozjum ekologicznego w Łodzi Łagiewinkach 19-20 listopada 1988, Niepokalanów 1992, s. 9. 
zmian, efektów epidemiologicznych, zmian genetycznych i innych, negatywnie odbijających się na stanie zdrowia społeczeństwa ${ }^{10}$.

\section{Zadania edukacji proekologicznej}

Edukacja ekologiczna ma więc za zadanie budowanie nowej relacji między człowiekiem i jego środowiskiem życia, tak w ujęciu indywidualnym, jak i całego społeczeństwa. Jest ona ważnym elementem kształtowania osobowości, stopniowania wartości, motywacji działania oraz zwykłych umiejętności i wiedzy ogólnej ${ }^{11}$. Należy ją traktować jako nieodłączny element integralnego procesu edukacyjnego ${ }^{12}$, polityki informacyjnej, powszechnej ochrony zdrowia oraz długoterminowej strategii gospodarczej ${ }^{13}$, który w efekcie powinien zaowocować wykształceniem konkretnych i zdecydowanych proekologicznych postaw obywateli na płaszczyźnie prywatnej i społecznej, wynikających z określonej ugruntowanej etyki, moralności i kultury jednostki ${ }^{14}$. W efekcie dochodzi do uruchomienia mechanizmów ekono-

${ }^{10}$ Por. W. Borkowski, Terenowa edukacja ekologiczna, w: J. Leśniewska, J. W. Czartoszewski (red.), Edukacja w naturze, czyli jak pokochać, poznać, zrozumieć i chronić przyrodę, t. 2, Warszawa 2002, s. 39-45; J. W. Dobrowolski, dz. cyt., s. 138.

${ }^{11}$ Por. K. Smolak, Edukacja wśród przyrody, w: J. W. Czartoszewski (red.), Edukacja ekologiczna na progu XXI wieku. Stan, możliwości, programy, t. 1, Warszawa 2001, s. 125-126 . Właściwych efektów można oczekiwać jedynie przy wdrożeniu jej na poziomie międzynarodowym i tylko wówczas, gdy stanie się ona ważnym elementem polityki państwa. Por. A. Papuziński, Edukacja ekologiczna jako element polityki ekologicznej państwa. Przyczynek do socjologicznej analizy problemu, w: J. W. Czartoszewski (red.), Edukacja ekologiczna, s. 15-27.

${ }_{12}$ Por. M. De Zan, Qualche riflessione sull'insegnamento della bioetica a scuola, „Bioetica" 2 (2000), s. 208-212; M. L. Di Pietro, Inserimento della bioetica nei curicoli scolastici: $i$ risultati di un'indagine conoscitiva, „Medicina e Morale” 2 (2000), s. 237-259. Edukacja ekologiczna nie powinna obejmować jedynie przekazywania wiedzy, ale musi łączyć się z działaniami wychowawczymi i formacyjnymi, szczególnie w odniesieniu do wychowanka w młodym wieku. Por. S. Kasprzak, Normatywny wymiar ekologicznych i sozologicznych idei w systemie prawa państwowego i kościelnego, Lublin 2003, s. 701; D. Kiełczewski, Ekologia społeczna, Białystok 1999, s. 148; I. Fudali, Kultura ekologiczna młodzieży, Kielce 2002, s. $161-196$.

${ }^{13}$ Por. D. Kiełczewski, Ekologia, s. 146. Znaczną pomocą są prowadzone badania socjologiczne, które pozwalają określić nie tylko stan ogólnej świadomości na temat stanu środowiska naturalnego, ale też korelacji między poziomem zanieczyszczenia a stanem zdrowia populacji. Zob. J. Wódź (red.), Problemy świadomości ekologicznej. Refleksje metodologiczne zwiqzane z badaniami świadomości ekologicznej mieszkańców Górnego Ślqska, Katowice 1990.

${ }^{14}$ Por. W. Tyburski, Pojednać się, s. 92-93. Prywatny i obywatelski stosunek do przyrody jest sumą obyczajów, poziomu kultury i sposobu podejścia do uregulowań prawa krajo- 
micznych zmuszających do postępowania zgodnego z założeniami ochrony środowiska i zasobów naturalnych, niezależnie od osobistego stosunku podmiotu do problematyki utrzymania walorów naturalnych; osiagnięcie celu ekonomicznego nie będzie możliwe kosztem środowiska i wbrew dobru wspólnemu ${ }^{15}$. Edukacja ekologiczna musi być powiązana z równoległym wychowywaniem społeczeństwa do rozumienia zagadnień środowiska i jego zagrożenia. Zintegrowane działania i potrzeba wypracowania instrumentów skutecznej ochrony wymaga interdyscyplinarnego działania dla uzyskania wymiernych rezultatów przedsięwzięć ekologicznych ${ }^{16}$.

\section{Potrzeba ekoteologii}

W procesie edukacji ekologicznej dopuścić należy również element religijny. Chodzi tu o łączenie sumienia człowieka z najwyższym autorytetem w zakresie podejmowania decyzji i postępowania. Szukając duchowych i teoretycznych uzasadnień dla zaspokojenia takiej potrzeby ludzkiej egzystencji, można odnaleźć je w dziedzinie ekoteologii ${ }^{17}$. Jest ona „połączeniem" chrześcijańskiego wychowania człowieka i świadomości współistnie-

wego i międzynarodowego, które powinno być włączone w proces dostosowywania i standaryzowania ustawodawstwa światowego w tym zakresie. Por. K. Równy, Członkostwo Polski w Unii Europejskiej a edukacja w zakresie wspólnotowego prawa ochrony środowiska, w: A. Przyborowska-Klimczak, Ekologia i Prawo, Lublin 1999, s. 53; D. Kiełczewski, Ekologia, s. 146. To wszystko wpisuje się w obszar pracy edukacyjnej na poziomie kognitywnym, emocjonalno-wolitywnym i behawioralnym. Szerzej na ten temat: W. Tyburski, Pojednać się, s. 97-98. Tak kompleksowe podejście do edukacji ekologicznej wymaga skutecznych rozwiązań na wszystkich stopniach edukacji, działalności zawodowej i powszechnego rozumienia problemu. Por. S. Olejnik, Kryzys moralny cywilizacji. Zachwianie hierarchii wartości we wspótczesnym świecie stechnicyzowanym, „Chrześcijanin w świecie” 12 (1980), nr 6, s. 25 -46; M. Fiałkowski, Człowiek wobec środowiska naturalnego, „Roczniki Teologiczne” XLIV (1997), z. 6, 1997, s. 151-161; Z. Czaja, P. Bajon, Alternatywna edukacja ekologiczna ogólne założenia, w: J. W. Czartoszewski (red.), Edukacja ekologiczna, s. 29-40; G. Embros, Filozoficzne uwarunkowania edukacji ekologicznej w ujęciu Zbigniewa Hulla, w: J. W. Czartoszewski (red.), Edukacja ekologiczna, s. 41-47. Omawiana edukacja w zakresie ochrony bogactw naturalnych jest także formą edukacji kulturowej, wyzwalającą w człowieku naturalne skłonności do integrowania się z przyrodą. Por. S. Kasprzak, dz. cyt., s. 698; D. Kiełczewski, Elementy prawa ponadustrojowego w prawie ochrony środowiska, w: J. M. Dołega, J. Sandner (red.), Świadomość i edukacja ekologiczna, Warszawa 1998, s. 84.

${ }_{15}$ Por. S. Kasprzak, dz. cyt., s. 698; A. Papuziński, Edukacja ekologiczna, s. 68-69.

${ }^{16}$ Por. K. Równy, dz. cyt., s. 51-86.

17 Por. S. Urbański, Ekoteologia duchowości człowieka, „Ateneum Kapłańskie” 138 (2002), nr 3, s. 477-478; J. Nagórny, Teologia ekologii, w: J. Nagórny, J. Gocko (red.), Ekologia. Przestanie moralne Kościoła, Lublin 2002, s. 187-203. 
nia w harmonii z przyroda, prowadzącą do pełniejszej integracji z Bogiem. Jest powiązaniem biologicznego istnienia człowieka $\mathrm{z}$ jego teologicznym myśleniem. Właśnie to kompleksowe analizowanie rzeczywistości pozwala odkrywać istnienie „wyższej logiki” w harmonii i pięknie otaczającego świata ${ }^{18}$. Współczesna edukacja ekologiczna musi rodzić potrzebę dialogu człowieka ze środowiskiem. Tenże dialog, odrzucając instrumentalne traktowanie przyrody, a więc przekonanie o jej wartości jedynie jako wartości użytkowej, które prowadzi do niszczenia tego, co jeszcze pozostało, uczy poszanowania bogactw naturalnych, respektowania autonomicznych praw przyrody, umiejętności współżycia i korzystania z niej oraz relacjonowania się, tj. dostrzegania w niej dobra, wyczulenia i uwrażliwiania na przejawy wyrządzanego jej zła ${ }^{19}$.

Do podstawowych inicjatyw wychodzących naprzeciw naglącym wymogom rozwijania wychowania ekologicznego należy zaliczyć dostosowywanie programów szkolnych do potrzeb i możliwości dziecka na wszystkich poziomach edukacji. Budzenie świadomości ekologicznej powinno rozpoczynać się od najmłodszych lat i być dostosowane do możliwości percepcji

18 Por. W. Tyburski, Etyka i ekologia, Toruń 1995, s. 109-110.

19 Na edukację do dialogu człowieka z przyrodą składają się określone zadania. Wynikają one z faktu, że: człowiek stanowi integralną część środowiska przyrodniczego i poddany jest tym samym prawom co inne jego elementy; człowiek jest w stanie kontrolować przyrodę, wykorzystując jej siły w granicach rządzących nią praw; należy utrzymać zdolności samoodnawiania środowiska, które jest podstawą istnienia jednostki; postawa pojednania, dialogu i opiekuństwa musi zająć miejsce egoistycznego nastawienia do dóbr oferowanych przez przyrodę. Por. W. Tyburski, Etyka i ekologia, s. 113-114.

Na doniosłość aspektu edukacyjnego wyraźnie wskazuje również Ustawa Prawo Ochrony Środowiska z dnia 27 kwietnia 2001. Problematyka edukacji ekologicznej rozpatrywana jest w dziale VIII tytułu I w art.77-80. W art. 77 ust. 1 mówi się, że: „Problematykę ochrony środowiska i zrównoważonego rozwoju uwzględnia się w podstawach programowych kształcenia ogólnego dla wszystkich typów szkół”. Natomiast w ustępie 2 czytamy: „Obowiązek, o którym mowa w ust. 1, obejmuje również organizatorów kursów prowadzących do uzyskania kwalifikacji zawodowych". (Dz. U. z dnia 20 czerwca 2001 r. Nr 62, poz. 627). Ten obowiązek prawny zbiega się z popularnymi dziś ekologicznymi inicjatywami edukacyjnymi, łączącymi się z ogólnym wychowaniem społecznym. Por. A. Pawłowski, Edukacja ekologiczna $w$ rodzinie. Uwagi do dyskusji, w: J. W. Czartoszewski (red.), Etyka środowiskowa wyzwaniem XXI wieku, t. 3, Warszawa 2002, s. 193-199; A. Kowalak, Etyczne aspekty edukacji środowiskowej w świetle wybranych teorii edukacyjnych, w: J. W. Czartoszewski (red.), Etyka środowiskowa, s. 133-140; D. Strzała, Edukacja ekologiczna w aspekcie etyki środowiskowej, w: J. W. Czartoszewski (red.), Etyka środowiskowa, s. 115-131.

Ogromne znaczenie w społecznej edukacji ekologicznej mają współczesne mass media. Zobowiązująco w tym sensie brzmi art. 78 niniejszej ustawy: „Środki masowego przekazu są zobowiązane kształtować pozytywny stosunek społeczeństwa do ochrony środowiska oraz popularyzować zasady tej ochrony w publikacjach i audycjach" (art. 78, Dz. U. z dnia 20 czerwca 2001 r., $\mathrm{Nr} 62$, poz. 627). 
dziecka. Punktem wyjścia i terenem weryfikacji przyswajanych zasad poszanowania środowiska powinna być jednak rodzina. Inne jednostki i instytucje wychowawcze powinny natomiast wspierać to podstawowe środowisko wychowawcze ${ }^{20}$. Szeroko zakrojona współpraca środowiska domowego ze szkołą i organizacjami pozaszkolnymi jest niezbędna, gdyż wychowanie to proces mozolny i długofalowy ${ }^{21}$. W przypadku wychowania ekologicznego ma to tym większe znaczenie, że pomaga ono w przeciwdziałaniu licznym, negatywnym efektom zdrowotnym powszechnie spotykanym u dzieci i młodzieży na terenach zdewastowanych ${ }^{22}$.

W procesy edukacji ekologicznej obok nauczycieli powinni czynnie włączyć się więc katecheci. W swoim nauczaniu powinni opierać się zarówno na prawnych aktach państwowych, jak i na sugestiach społecznej nauki Kościoła. Szczególnie dużo miejsca kwestiom ekologicznym w encyklikach i przemówieniach poświęcili papieże Paweł VI i Jan Paweł II ${ }^{23}$. Konkretnym działaniem w tym kierunku jest również coraz szersze zainteresowanie teologów, którzy w sposób oczywisty wiążą potrzebę katechetycznego uświadamiania ekologicznego z globalnym kształtowaniem osobowości człowie$\mathrm{ka}^{24}$. Dzieje się tak zapewne dlatego, iż społeczeństwa powoli dojrzewają do przekonania, że świadomość ekologiczna jest traktowana jako jej element trwały, zamierzony na całe życie, w trakcie którego wszyscy członkowie społeczeństwa przyswoją sobie wiedzę i wartości, nabędą umiejętności i doświadczeń, a w konsekwencji przyczynią się do naprawiania stosunków między ludźmi i środowiskiem. W takim kontekście jawi się więc jako coś więcej niż tylko element wychowania podstawowego; należy ją odbierać jako podstawę kształtowania innego niż konsumpcyjny styl życia, odmienny sposób współistnienia ludzi obok siebie i człowieka z naturą. Z tego względu

${ }^{20}$ Por. M. Fiałkowski, dz. cyt., s. 151-161; S. Kasprzak, dz. cyt., s. 707.

${ }^{21}$ Por. M. Fiałkowski, dz. cyt., s. 151-161.

${ }^{22}$ Por. M. Ręka, Ekologiczne zagrożenie środowiska a poziom niepokoju u dzieci, ,Summarium" 24-25 (1995-1996), s. 91-97.

${ }^{23}$ Żywe zainteresowanie hierarchów Kościoła problemami ekologii wynika ze świadomości zagrożenia nie tylko środowiska życia człowieka, ale przede wszystkim jego samego: jego naturalnej i moralnej struktury osobowościowej, w którą został wyposażony. Ponadto jest więcej niż prawdopodobne, że zachowania dewiacyjne, stany apatyczne, frustracyjne, choroby i schorzenia psychiczne, migreny, stany lękowe, zniechęcenie, utrata sensu życia mogą być następstwem poważnych zakłóceń i deformacji środowiska przyrodniczego. Por. J. Mariański, Problemy ekologiczne w społecznym nauczaniu Kościoła, w: L. Pawłowski, S. Zięba (red.), Humanizm ekologiczny, t. 1, Lublin 1992, s. 51-70; E. Sgreccia, M. Pennacchini, M. B. Fisso, I documenti della Chiesa sulla questione ambientale, „Medicina e Morale” 4 (2000), s. 635-675.

${ }^{24}$ Por. S. Dziekoński, Teologiczne podstawy wychowania ekologicznego w katechezie, „Ateneum Kapłańskie” 138 (2002), nr 3, s. 481-496. 
proces edukacji przyrodniczej powinien objąć nie tylko instytucje szkolne i uniwersyteckie, ale i szerokie rzesze dorosłych ${ }^{25}$. Ma to na celu przekonać wszystkich, niezależnie od wieku, o istnieniu ścisłego powiązania pomiędzy postępem prac nad ochroną środowiska a jakością życia, które stało się palącym problemem wielu społeczeństw krajów wysoko uprzemysłowionych. Nabycie tych wiadomości pozwoli przekonać się, że nie ma żadnej sprzeczności pomiędzy rozwojem społeczno-ekonomicznym kraju a ochroną jego zasobów naturalnych, co może zaowocować jedynie poprawieniem warunków bytowych człowieka. Należy uświadamiać istnienie wzajemnych zależności człowieka i jego kondycji zdrowotnej od warunków i czynników środowiskowych oraz wpływu rozwoju cywilizacji. Należy kształtować umiejętność racjonalnego oceniania sytuacji w środowisku oraz postawę emocjonalnego zaangażowania i poczucia osobistego zagrożenia negatywnymi i nieodwracalnymi zmianami w ekosystemach przyrodniczych. Zdegradowane środowisko przyrodnicze jest przyczyną wielu chorób, często do końca nieuświadomionych ${ }^{26}$. Konieczne jest więc wyzwolenie poczucia współodpowiedzialności, wyrabianie wewnętrznej potrzeby ochrony i gotowości do angażowania się w inicjatywy proekologiczne ${ }^{27}$.

${ }^{25}$ Por. E. Trzaskowska, O potrzebie i formach edukacji ekologicznej, w: L. Pawłowski, S. Zięba (red.), dz. cyt., s. 97-103; J. Woźniakowski, Przyroda i sztuka, „Znak” 27 (1975), nr 9, s. 1113-1121; J. Łukomski, Zagrożenie środowiska naturalnego, „Roczniki Filozoficzne" 42 (1994), z. 3, s. 65-97; S. Kasprzak, dz. cyt., s. 711.

${ }^{26}$ Por. E. Trzaskowska, dz. cyt., s. 97-103; S. Kasprzak, dz. cyt., s. 712.

${ }^{27}$ Edukacja ekologiczna na płaszczyźnie szkół wyższych i uniwersytetów należy dojednych z najważniejszych. Kształci się tam bowiem przyszłych decydentów różnego szczebla, mogących wpływać bezpośrednio na jakość środowiska przyrodniczego i poziom życia obywateli. Uniwersytety przygotowują przyszłych nauczycieli, rzesze techników, społeczną warstwę inteligencji, która ma być przykładem dla ogółu społeczeństwa. Por. E. Trzaskowska, dz. cyt., s. 97-103; W. Isidorow, J. Jaroszyńska, Chemiczne problemy ekologii, Białystok 1999, s. 219; J. Jaroń, Udziat nauczycieli akademickich - humanistów - w programowaniu wiedzy ekofilozoficzno-bioetycznej, w: J. W. Czartoszewski (red.), Edukacja ekologiczna, s. 49-57. Na tym poziomie naukowego kształtowania stanu świadomości ekologicznej edukacja powinna dotyczyć charakterystyki podstawowych problemów przyrody i środowiska życia człowieka z szerokim uwzględnieniem globalnych i lokalnych aspektów ekologiczno-przyrodniczych, społeczno-ekonomicznych, medyczno-psychologicznych, inżynieryjno-technicznych i humanistycznych. Por. M. Langiewicz, Katolicka myśl ekofilozoficzna na przyktadzie działalności Katedry filozofii ekologii na Uniwersytecie Kard. Stefana Wyszyńskiego w Warszawie, „Ateneum Kapłańskie” 138 (2002), nr 3, s. 515-532. Powinna uwzględniać również podstawową orientację w funkcjonowaniu mechanizmów naturalnych, których struktura ekologiczna daje bazę i podstawę do życia na Ziemi, oraz w roli i miejscu człowieka w tymże środowisku. Por. E. Trzaskowska, dz. cyt., s. 97-103. 


\section{Potrzeba wspóldziałania Kościoła ze świeckimi instytucjami wychowawczymi w zakresie edukacji ekologicznej}

Godnym podkreślenia jest fakt, że w tę trudną pracę edukacyjną włączył się również Kościół. Na forum duszpasterskim podejmuje działanie uwrażliwiania świadomości swoich wiernych na potrzebę roztoczenia opieki nad dobrami, które z natury rzeczy służą naszej zdrowiej kondycji życiowej. Środowisko przyrodnicze stanowi dla każdego człowieka podstawowe uwarunkowanie życia i właściwego rozwoju uczuciowego, psychicznego, duchowego, a także religijnego ${ }^{28}$, uwarunkowanie myślenia, mentalności, zachowania, stanu ducha, kondycji fizycznej. Do obowiązków prawodawcy kościelnego, hierarchów i nauczycieli szkół katolickich należy apelowanie o życie w poszanowaniu natury i apelowanie o chrześcijańską postawę w tym względzie ${ }^{29}$.

Przyroda jest wartością dla każdego człowieka, a jednocześnie dobrem wszystkich ludzi. Poszanowanie środowiska ze wszystkimi (ożywionymi i nieożywionymi) elementami składowymi jest conditio sine qua non naszego życia. Zyski z tego płynące, podobnie jak piękno przyrody, są oferowane wszystkim, dlatego nikt nie może uzurpować sobie prawa lub przywileju do niszczenia środowiska lub przywłaszczania jego części. Kompleksowe lub wybiórcze, nieświadomie lub umyślne, niszczenie elementów biosfery odbiera możliwość korzystania z jej szczególnych wartości użytkowych innym ludziom $^{30}$.

Przedstawione treści stanowiska Kościoła katolickiego powinny znaleźć się w programach duszpasterskich tematów nauczania i katechez jako okazja do refleksji (również teologicznej) na temat przyczyn kryzysu ekologicznego i obniżenia obyczajowości, przekładających się na zaniedbania spraw ochrony środowiska. Mogłoby to wpłynać na uwrażliwienie sumień na problem degradacji otoczenia, kształtowanie relacji między ludźmi, pozytywne nastawienie do wszelkich form życia. Wielokierunkowe i wielowymiarowe krzewienie edukacji ekologicznej (w szkołach, nauczaniu Kościoła, sank-

28 Por. B. Jurczyk, Człowiek miarq troski o środowisko naturalne, „Roczniki teologiczne" 40 (1993), nr 3, s. 75-93.

29 Por. D. Zimoń, Troska Kościoła o przyszłość Ślaska. List pasterski na uroczystość Świętego Franciszka, „Chrześcijanin w świecie” 157 (1986), s. 109-113; List Pasterski Episkopatu Polski na temat ochrony środowiska z dnia 2 maja 1989 roku podjęty na 234 Konferencji Plenarnej Episkopatu Polski, w: S. C. Napiórkowski, W. Koc (red.), dz. cyt., s. 169-176; J. Ostynowicz, Przyroda głosi Boga, „Materiały Problemowe” 9 (1978), s. 125-127; J. Łukomski, Edukacyjna rola liturgii w Kościele katolickim. Aspekt ekologiczny, w: J. W. Czartoszewski (red.), Edukacja ekologiczna, s. 155-180.

30 J. Ostynowicz, Szanuj przyrodę, „Materiały Problemowe” 9 (1978), s. 127-128. 
cjach karnych itd.) jest niezbędne w globalnym wysiłku zmiany nastawienia ludzi do własnego środowiska życia, ponieważ powszechnie dostrzegane wielowiekowe zaniedbania wciąż nie są przestrogą $\mathrm{w}$ podejmowaniu nierozważnych decyzji i ingerencji w sferę naturalnych mechanizmów funkcjonowania, nadużyciach i irracjonalnych zachowaniach. Współdziałanie Kościoła i szkoły może natomiast prowadzić do wykreowania właściwych postaw, szczególnie młodego człowieka, wobec zagadnień ochrony środowiska oraz skutecznego podnoszenia świadomości oraz poszanowania przyrody, wypracowanych w oparciu o umiejętne włączanie tych kwestii do zagadnień życia religijnego ${ }^{31}$.

\section{The Integrative Role of Religious Instruction in Pro-Ecological Education (Summary)}

Curricula taught across all tiers of schooling are devised to promote proecological attitudes. Religion instructors, alongside educators, should thus be involved in the schooling processes. Their teaching practice ought to remain in line with existing legislation and the social doctrine of the Church. Ecological issues were in the focus of special attention of the Pope Paul VI and John Paul II. Steps to bring ecology into religion teaching are also taken in the form of an interest which religion instructors express about the need to combine eco-awareness imparted as part of religion classes with holistic approach towards the moulding of human personality.

Every man tends to perceive nature as a value and simultaneously as the common good of humanity. Respect for the environment, including all its living and non-living components, is regarded as the sine qua non of our life. The Catholic Church's stance on environmental issues ought to be incorporated into pastoral preaching and religion classes to provide food for thought. Eco-awareness is a factor shaping relationships between people and forging a positive attitude towards other forms of life. Joint collaboration of the Church and school may inculcate in young people respect for nature and encourage them to adopt a proper attitude towards ecological matters, which can be attained through assimilation of the latter into religious education.

${ }^{31}$ Por. E. Trzaskowska, dz. cyt., s. 97-103; S. Kasprzak, dz. cyt., s. 718. 